\title{
GPS adatok mérése és feldolgozása NI, LabVIEW szoftverrel
}

\author{
Balogh Ildikó Julianna \\ Mechatronikai Tanszék \\ Debreceni Egyetem, Müszaki Kar \\ Debrecen, Magyarország \\ baloghildiko55@gmail.com
}

\author{
Sarvajcz Kornél \\ Mechatronikai Tanszék \\ Debreceni Egyetem, Müszaki Kar \\ Debrecen, Magyarország \\ sarvajcz@eng.unideb.hu
}

\author{
Dr. habil Husi Géza \\ Mechatronikai Tanszék \\ Debreceni Egyetem, Müszaki Kar \\ Debrecen, Magyarország \\ husigeza@eng.unideb.hu
}

\begin{abstract}
Absztrakt-Ezen fejlesztés keretein belül egy GPS adatok mérésére, feldolgozására képes program készült el LabVIEWban, amely képes a feldolgozás után az adatokat olyan formátumú fájlba kimenteni, amely alkalmas térkép megjelenítő szolgáltatások általi betöltésre, mint például a Google Map vagy Google Earth.
\end{abstract}

Kulcsszavak-gps; gnss; nmea; feldolgozás; LabVIEW; gpx; (kulcsszavak)

\section{BEVEZETŐ}

A kutatómunka témája a GPS adatok feldolgozása LabVIEW programozási nyelvben, amellyel az volt a cél, hogy a GPS vevőkészülék által közvetített adatokat a LabVIEW képes legyen fogadni ezeket az adatokat mérés közben fel tudja dolgozni, megjelenítésre alkalmas formátumba átalakítsa őket, majd megjelenítse, ezek után pedig egy olyan fájl formátumba mentése az adatoknak, amely megjeleníthető térképmegjelenítő alkalmazásokban, így a mérésünket, tehát a megtett útvonalunkat a keletkező fájl feltöltése után megtudjuk grafikusan is jeleníteni.

\section{MÜHOLDAS HELYMEGHATÁROZÁS}

\section{A. GNSS rendszerek}

A globális navigációs müholdrendszer (Global Navigational Satellite System - GNSS) a helymeghatározás, a navigáció és az időmeghatározás feladatainak megoldását hivatott szolgálni mesterséges holdak segítségével. A GNSS technológiával végzett müholdas helymeghatározás azon alapszik, hogy a mesterséges holdak helyzete ismert, azok - geometriai értelemben - egy adott időpillanatban ismert pontoknak tekinthetők egy definiált vonatkoztatási rendszerben. A műholdak pályaadatait ugyanis ismert helyzetü földi pontokon észlelő pályakövető állomások meghatározzák és ezeket az ún. navigációs adatokat a mesterséges holdak saját maguk sugározzák. A felhasználó (a GNSS vevő) közvetett módon távolságot határoz meg a vevő és néhány, egyidőben (szimultán módon) észlelt mühold között, majd ezen távolságok és a mühold-pozíciók ismeretében a vevő helyzete egy megadott vonatkoztatási rendszerben kiszámítható. A vevő sebessége is számítható, mivel ismert azon időtartam, ami a vevő két helyzet-meghatározása között eltelik. A GNSS a globális müholdas helymeghatározó rendszerek (GPS NAVSTAR, GLONASSZ, Galileo, COMPASS, GINSS) közös elnevezése. Ezek közül jelenleg a GPS (Global Positioning System) és GLONASSZ (Globalnaja Nawigazionnaja Sputnikowaja Sistema) müködik [1].

A GPS rendszerben az egyenlítő mentén $30^{\circ}$ hosszúságkülönbséggel elosztott hat pályán 24 mesterséges hold kering. A holdak pályasíkjai $55^{\circ}$-os szöget zárnak be az egyenlítő síkjával. A holdpályák száma, helyzete a mesterséges holdak száma és elhelyezkedése a pályákon azt a célt szolgálja, hogy teljes kiépítésben a Föld bármely pontján, bármely időpontban egyszerre négy mesterséges hold észlelésre alkalmas helyzetben, azaz legalább $15^{\circ}$-ra a látóhatár síkja felett legyen [2].

\section{B. A müholdas helymeghatározás vonatkoztatási rendszerei}

A GPS múholdak által sugárzott fedélzeti pályaadatok vonatkoztatási rendszere a WGS84 (Geodéziai Világrendszer World Geodetic System) [1].

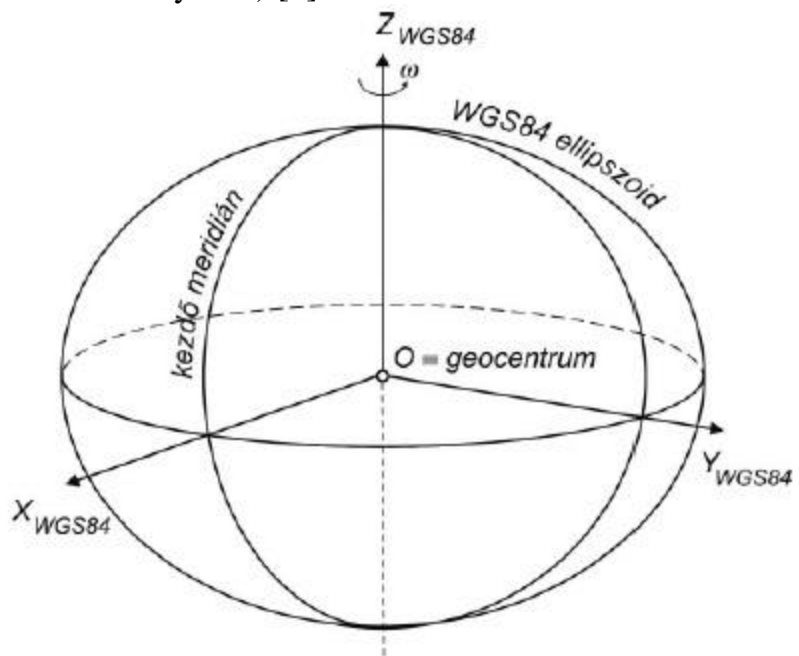

1. ábra A WGS84 tnegelyei és vonatkoztatási ellipszoidja [1]] 
Ez a rendszer a GPS alaprendszer fenntartójának földi vonatkoztatási rendszere, amelyet a követőállomások koordinátái valósítanak meg. A rendszer fenntartói politikai szempontból az Egyesült Államok Nemzetvédelmi Minisztériuma (Department of Defense -DoD) szakmai szempontból az amerikai térképészeti szolgálat (National Geospatic Intelligence Agency - NGA). A WGS84 kezdeti 1984. évi meghatározása doppleres müholdmegfigyeléseken alapszik, ahol pályameghatározásban résztvevő állomások száma változott, kezdetben 5 volt, ami később 15-re bővült [1].

\section{Müholdas helymeghatározás elve}

Ha feltételezzük, hogy az S-el jelölt müholdon és az ismeretlen helyzetü $P$ jelü vevőkészüléken is egy-egy tökéletesen szinkronizált és pontos óra van elhelyezve, akkor a mühold által a GPS időskálán $t_{0}$ időpillanatban kibocsátott kódolt jel a vevőhöz $\Delta \mathrm{t}$ idő múlva érkezik. Ha ezt a futási időt sikerül megmérni, akkor a futási időből egy a c fénysebesség ismeretében a vevő és a mühold közötti $\rho$ geometriai távolság meghatározható [1].

$$
\rho=c * \Delta t
$$

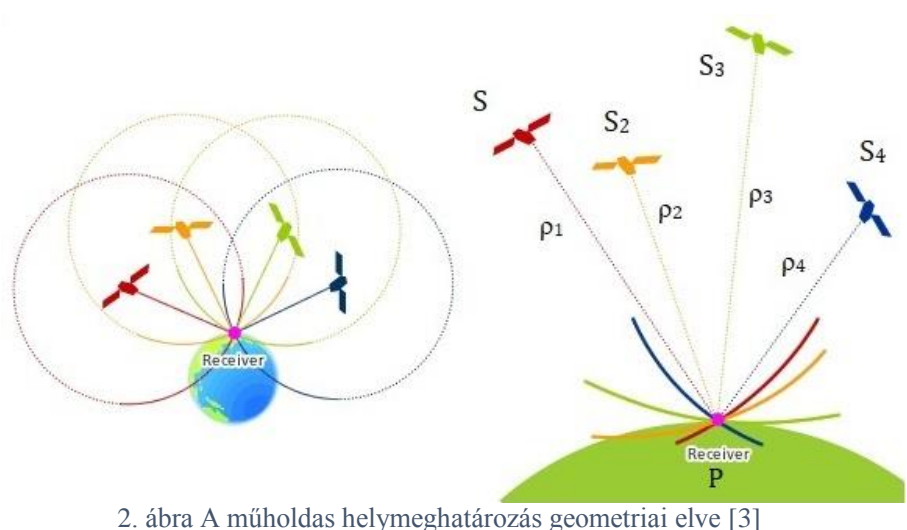

Ha a $t_{0}$ időpillanatban a ismert helyzetü $S_{2}$ és $S_{3}$ müholdakra is végzünk távolságmérést és a holdak geometriai szempontból megfelelö elhelyezkedésüek, akkor a vevő helyzete térbeli ívmetszéssel meghatározható. Abban az esetben, ha három távolságot mérünk, akkor három egyenlet írható fel három ismeretlen összetevő kiszámítására [1] [4].

Mivel a gyakorlatban a vevőben nem atomóra van elhelyezve, hanem kvarc óra, ami nem olyan pontos, mint az atomórák, így az nem olyan pontos, mint a müholdakon elhelyezett atomóra, így mindig van hiba a mesterséges holdak órájához képest. Ezt az órahibát $\delta$ jelöljük. A futási idő mérése ezen óra hiba miatt $\mathrm{c}^{*} \delta=\Delta \rho$ értékkel hibás lesz. A vevő órahibája miatt mért közelítő távolságot pszeudó távolságnak nevezzük. Szakkönyvekben R-rel jelölik [1].

$$
R=\rho+\Delta p=\rho+c * \delta
$$

A vevő órahibájával mindig számolni kell, így összesen négy meghatározandó paraméterünk van. Ezek meghatározásához négy darab mért távolságra az az négy müholdra van szükség [1] [4].

\section{UBLOX NEO-6 GPS VEVÖKÉSZÜLÉK}

Az eltervezett feladat teljesítéséhez szükség volt egy külső GPS vevő készülék. Ilyen készülékből több féle is van. A Debreceni Egyetem, Mechatronikai Tanszékén a drónokhoz az U-blox NEO-6 modul sorozatának M-es modelljét használják, amely az u-blox6 pozíció motorjának nagy teljesítményét hozza a miniatür NEO formához. Az u-blox 6-ot az alacsony energiafogyasztást és alacsony költségeket észben tartva tervezték. Ezek a rugalmas és költséghatékony vevők számos csatlakoztatási lehetőséget kínálnak egy miniatür 16 x 12,2 x 2,4 mm-es csomagban. A kutatócsoport által használt GPS vevő készülék képes adatokat továbbítani, USB, SPI, UART és DDC-n keresztül[3]. Ezek közül a projekt során az UART kapcsolatot használtuk. Továbbá ez a vevő készülék az adatokat három különböző szabvány szerint tudja továbbítani mind USB, UART és DDC interfészen keresztül Ezek az NMEA, UBX és RTCM, melyek közül az NMEA protokollt használtuk.[5][6].

A GPS konfigurálása során az adatátviteli sebességet 9600 bit/s -re választottuk, ez volt megadva alapértelmezettként is a GPS vevőkészüléknél. Az alapbeállításoknak megfelelően a vevőkészülék az NMEA szabvány üzeneteit közvetítette, de mivel számunkra nem volt szükséges az összes adatsort használni, mivel nem feltétlenül szükséges a GPX fájl megvalósításához, ezért az RMC és GGA-s sorokon kívül a többi sort letiltottuk. A konfigurálást az u-center nevezetü programban hajtottuk végre.

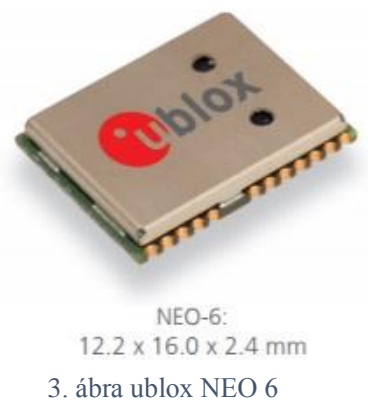

\section{NMEA PROTOKOLL}

Az NMEA üzenetek, amelyeket a GPS vevő továbbít az NMEA 01832.3 verziójára vannak alapozva [6]. Az NMEA 0183 kombinált villamos és adat specifikáció a tengeri elektronika, például a visszhangjelzö, a hangjelzők, a szélmérők, az iránytük, a robotpilóta, a GPS vevőkészülékek és számos más típusú eszköz kommunikációjához. Az NMEA 0183 szabvány egy egyszerü ASCII, soros kommunikációs protokollt használ, amely meghatározza, hogy miként továbbítják az adatokat egy "mondat" -ban egy "beszélő" -től több „hallgató” -hoz. Közbenső bővítők használatával a „beszélő” egyirányú beszélgetést szinte korlátlan számú hallgatóval folytathat és multiplexerek használatával több szenzor beszélhet egyetlen számítógép porttal [7].

Az NMEA üzenetek mindig ,\$” jellel kezdődnek utána, következik a címzett, ami, hogy ha GPS vevőkészülékről van szó akkor GP-vel, ha pedig saját üzenetről P-vel kezdődik. A 
következő 3 karakter határozza meg az adat formátumát, utána következik az értékeket tartalmazó „mező”, amelyek vesszőkkel vannak elválasztva, majd az ellenőrző rész mindig „*" -val kezdődik, és két karaktert tartalmaz, amelyek egy hexadecimális számot képviselnek. Azok az adat mezők, ahol nem érkezett információ üresen maradnak [7][8].

Az NMEA üzenetek közül a választott GPS vevő készülék 14 megjelenítésére alkalmas (DTM, GBS, GGA, GLL, GPQ, GRS, GSA, GST, GSV, RMC, THS, VTG, ZDA) de ezek közül csak kettöt használtunk, tekintettel, hogy azok tartalmazzák a legfontosabb (szélesség, hosszúság, tengerszint feletti magasság, idő, és dátum) adatokat. Ez a két üzenet az RMC (Recommended minimum data) illetve GGA (Global positioning system fix data) üzenetek.

\section{A. RMC (Recommended minimum data)}

Példa:

\$GPRMC,083559.00,A,4717.11437,N,00833.91522,E,0.004,7 7.52,091202,,,A*57

\begin{tabular}{|c|c|c|c|}
\hline $\begin{array}{l}\text { Mezö } \\
\text { száma }\end{array}$ & Példa & Formátum & Leírás \\
\hline 0 & \$GPRMC & string & Üzenet ID \\
\hline 1 & 083559.00 & hhmmss.ss & $\begin{array}{l}\text { UTC idő, } \\
\text { jelenlegi idő }\end{array}$ \\
\hline 2 & $\mathrm{~A}$ & ddmm.mmmm & $\begin{array}{l}\text { Állapot } \\
\mathrm{A}=\text { Érvényes, } \\
\mathrm{V}=\text { Érvénytelen }\end{array}$ \\
\hline 3 & 4717.11437 & ddmm.mmmm & $\begin{array}{l}\text { szélességi fok, } \\
\text { fok }+ \text { szögperc }\end{array}$ \\
\hline 4 & $\mathrm{~N}$ & character & $\begin{array}{l}\text { N/S, Észak } \\
\text { vagy Dél }\end{array}$ \\
\hline 5 & 00833.91522 & ddmm.mmmm & $\begin{array}{l}\text { hosszúsági } \\
\text { fok, } \\
\text { fok+szögperc }\end{array}$ \\
\hline 6 & $\mathrm{E}$ & character & $\begin{array}{l}\text { E/W, Kelet } \\
\text { vagy Nyugat }\end{array}$ \\
\hline 7 & 0.004 & numeric & $\begin{array}{l}\text { A földhöz } \\
\text { viszonyított } \\
\text { sebesség knots }\end{array}$ \\
\hline 8 & 77.52 & numeric & $\begin{array}{l}\text { Pálya a föld } \\
\text { felett (fok) }\end{array}$ \\
\hline 9 & 091202 & ddmmyy & $\begin{array}{l}\text { Dátum } \\
\text { nap/hó/év }\end{array}$ \\
\hline 10 & - & numeric & $\begin{array}{l}\text { Mágneses } \\
\text { variációs érték } \\
\text { (fok) }\end{array}$ \\
\hline 11 & - & character & $\begin{array}{l}\text { Mágneses } \\
\text { variáció E/W } \\
\text { jelző }\end{array}$ \\
\hline 12 & - & character & Mód jelző \\
\hline 13 & $* 57$ & hexadecimal & Checksum \\
\hline 14 & - & character & $\begin{array}{l}\text { Carriage } \\
\text { Return és Line } \\
\text { Feed }\end{array}$ \\
\hline
\end{tabular}

1. táblázat [7]

\section{B. GGA (Global positioning system fix data)}

Példa:

\$GPGGA,092725.00,4717.11399,N,00833.91590,E,1,8,1.01,4 99.6,M,48.0,M, $0 * 5 \mathrm{~B}$

\begin{tabular}{|c|c|c|c|}
\hline $\begin{array}{l}\text { Mezö } \\
\text { száma }\end{array}$ & Példa & Formátum & Leírás \\
\hline 0 & \$GPGGA & string & Üzenet ID \\
\hline 1 & 092725.00 & hhmmss.ss & $\begin{array}{l}\text { UTC idö, jelenlegi } \\
\text { idő }\end{array}$ \\
\hline 2 & 4717.11399 & ddmm.mmmm & $\begin{array}{l}\text { szélességi fok, } \\
\text { fok }+ \text { szögperc }\end{array}$ \\
\hline 3 & $\mathrm{~N}$ & character & N/S, Észak vagy Dél \\
\hline 4 & 00833.91590 & ddmm.mmmm & $\begin{array}{l}\text { hosszúsági fok, } \\
\text { fok+szögperc }\end{array}$ \\
\hline 5 & $\mathrm{E}$ & character & $\begin{array}{l}\text { E/W, Kelet vagy } \\
\text { Nyugat }\end{array}$ \\
\hline 6 & 1 & digit & $\begin{array}{ll}\text { pozíció } & \text { javítás } \\
\text { állapotjelző } & \\
\end{array}$ \\
\hline 7 & 8 & numeric & $\begin{array}{l}\text { Használt müholdak } \\
\text { száma 0-12 -ig }\end{array}$ \\
\hline 8 & 1.01 & numeric & $\begin{array}{l}\text { HDOP, Horizontal } \\
\text { Delution of Precision }\end{array}$ \\
\hline 9 & 499.6 & numeric & $\begin{array}{l}\text { Tengerszintfeletti } \\
\text { magasság }\end{array}$ \\
\hline 10 & $\mathrm{M}$ & character & mértékegység, méter \\
\hline 11 & 48.0 & numeric & Geoid elválás \\
\hline 12 & $\mathrm{M}$ & character & mértékeygség, méter \\
\hline 13 & - & numeric & $\begin{array}{l}\text { Differenciálkorrekció } \\
\text { kora, üres, ha DGPS } \\
\text { nem használt }\end{array}$ \\
\hline 14 & 0 & numeric & $\begin{array}{l}\text { Diff. referencia } \\
\text { állomás azonosítója }\end{array}$ \\
\hline 15 & $* 5 \mathrm{~B}$ & hexadecimal & checksum \\
\hline 16 & - & character & $\begin{array}{l}\text { Carrige return és } \\
\text { Line Feed }\end{array}$ \\
\hline
\end{tabular}

\section{A PROGRAM MEGVALÓSÍTÁSA}

A programot úgy terveztük, hogy az képes legyen külső GPS egység által küldött adatok beolvasására, feldolgozására, illetve szerettük volna, ha képesek vagyunk ezeket az adatokat egy olyan formátumban menteni, amelyet képes megjeleníteni a Google Maps vagy más hasonló alkalmazás. Ehhez a GPX (GPS Exchange Format) formátumot választottuk, ami egy nyílt XML séma, amelyet a GPS alkalmazások közös adatformátumaként terveztek. Használható, pontok (waypoint), nyomvonalak (track), útvonalak (route) leírására. Az útpontok egymástól különálló pontokat jelentenek, amelyek nincsenek kapcsolatban egymással. A nyomvonal azokat a pontokat jeleníti meg, ahol már voltunk, tehát valaki rögzítette, hogy ott járt, míg az útvonal olyan pontokat is tartalmaz, ahova el szeretnénk jutni [9]. Ezek alapján arra a döntésre jutottunk, hogy nyomvonalként fogjuk majd menteni 
a beolvasott adatokat. A programot úgy szerettük volna elkészíteni, hogy az adatok fogadása közben, tehát a mérés közben a különböző adatok megjelenjenek különböző kijelzőkön is, illetve, hogy az eredeti GPS által küldött NMEA adatsorokat is el lehessen menteni. Első lépésként a program konfigurálja a portot a GPS beállításainak megfelelően, a különböző értékeket a Front Panelen megadhatók.

Ezután következik maga a mérés, amelyet mindaddig végzünk, amíg meg nem nyomjuk a STOP gombot. A mérés alatt a kijelzéshez először megvizsgáljuk, hogy érkezik-e adat, majd azt, hogy ez az érkező adat „\$”-val kezdődik-e. Abban az esetben, ha az elöző feltételek teljesülnek, akkor megvizsgáljuk, hogy több mint 30 karaktert tartalmaz-e az adatsor. Abban az esetben, ha ez nem teljesül akkor a kijelzőkön a „Nincs megfelelő mennyiségü adat” jelenik meg. Abban az esetben, ha több mint 30 karakter tartalmaz az érkező adatsor akkor megkezdődik az adatok átalakítása, majd kijelzése illetve a megfelelő adatok tömbökbe gyüjtése a mentéshez. A 30 karakternél kevesebb adat azt jelenti, hogy a GPS modul nem kapcsolódik megfelelö számú müholdhoz, és nem tudja megjeleníteni a paramétereket.

Az adatok kiolvasása úgy történik, hogy sorban először a RMC típusú adatsorozat érkezik, majd a GGA adatsorozat. Az adatok átalakításához először is a kapott NMEA üzenetsort elemeire kell bontani. Ezt úgy oldottuk meg, hogy addig keresi a program ,, ,"-t vagy , ,"-ot a szövegben, amíg már nem volt több találat; a , "” keresésére azért, van szükség mert az adatsor utolsó eleme után már nincs vessző hanem rögtön az ellenőrző rész következik, ami „,"'-gal kezdődik és utána egy hexadecimális szám van.

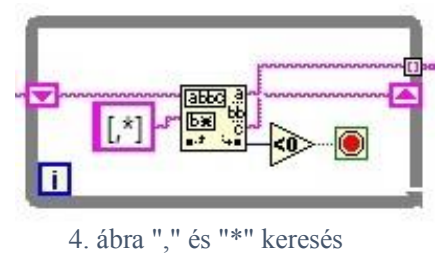

Az aktuálisan talált „, ," előtti szöveget sorszámozzuk (Tunel Mode: Indexing), így a ciklusból való kilépés után egy adattömbünk lesz, amelynek mindkét esetben 0 . eleme az NMEA kódolás típusát határozza meg tehát, hogy RMC vagy GGA típusú adat érkezett. A többi elem pedig a kódolásoknak megfelelő adatok értékeit tartalmazza megfelelő sorrendben. Ezután az adatokat lehetett külön-külön formázni, amit az alábbi folyamatábra alapján tettem meg.

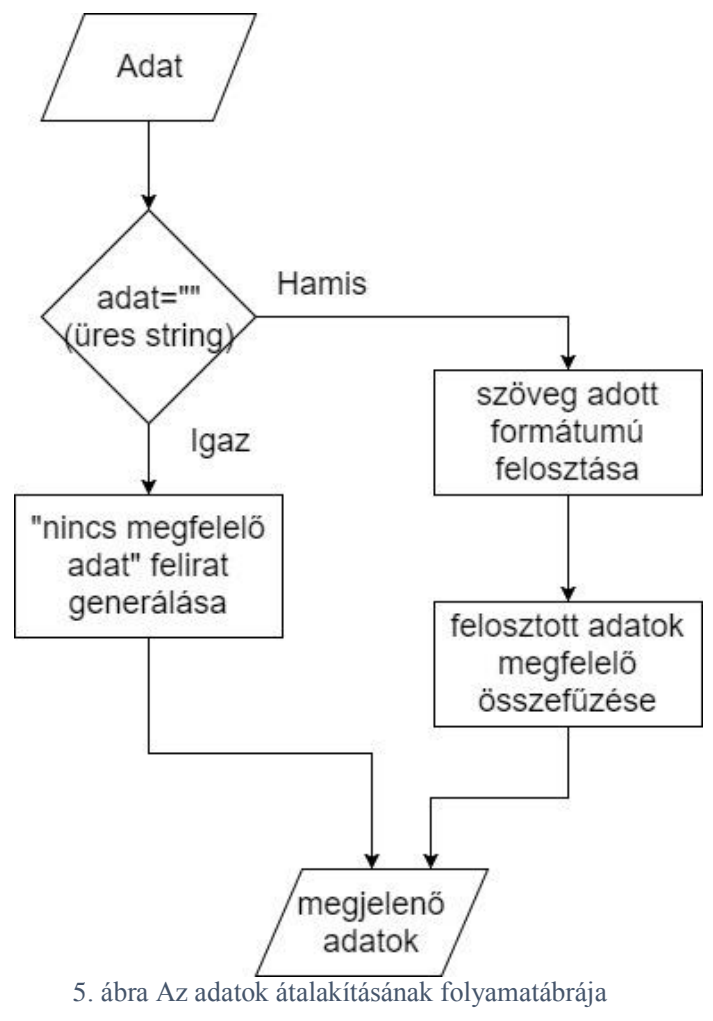

Az átalakítandó adatok a földrajzi szélesség, földrajzi hosszúság, dátum, idő, sebesség és tengerszint feletti magasság. Ezeket a megjelenítés, illetve a mentés szempontjából is más alakban mentettem el.

Az 5. ábrán is látható, hogy az átalakításhoz először a kapott elemet megvizsgáljuk, hogy tartalmaz e adatot vagy nem; ha nem érkezett adat abban az esetben az adott kijelzőn a ,nincs megfelelö adat" felirat jelenik meg. Abban az esetben, ha érkezett adat akkor ezt a szöveget bizonyos szempontok alapján felosztjuk, majd, ha szükséges matematikai átalakítást végzünk az egyes elemeken és utána újra összefüzzük a megfelelő sorrendben, megfelelő kiegészítésekkel, majd megjelenítjük, vagy a megfelelö tömbbe gyüjtjük, ha mentéshez szükséges.

Ez alapján az idő átalakítása úgy történik, hogy az idő estében a 9 karaktert, amit kapunk (pl.: 091526.00) az első hat karaktert levágjuk, majd felosztjuk 3db 2 számjegyből álló számra, tehát 09, 15 és 26-ra, majd ezeket a karkatereket a ,,:” kiegészítésekekel újra összefüzzük, így a kapott a szöveg, amely az időt jelképezi a következő lesz: „,09:15:26”.

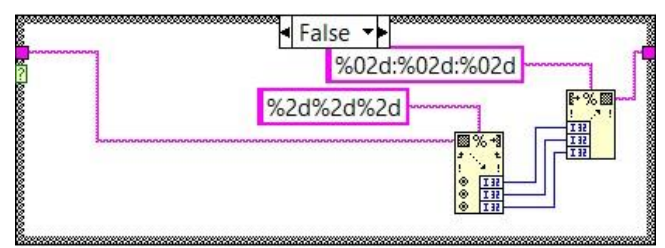

6. ábra Az idő átalakítása

A kijelzőn megjelenő értéket lokális időnek szántuk és ahhoz, hogy ez müködöképes legyen bármely időzónában 
bármely időpillanatban lokális dátum és időt egyszere kell megjelenítenem, ehhez a fenti ábrán ismertetett módon összefüztük az időt a megfelelő formátumba, majd elé füztük a dátum már formázott értékét, ennek átalakítását később ismertetjük. Ebben az esetben a következő értéket kapjuk: pl.: 2017-11-09 09:15:26 szövegként, amit átalakítottunk „Time Stamp" formátumba, ehhez már hozzá tudjuk adni az időzónának megfelelő értéket, majd átalakítjuk a kapott értéket szöveg formátumba.

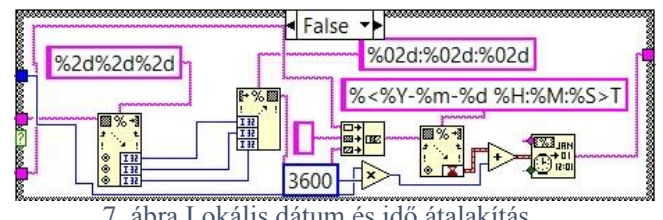

A dátum esetében 6 karakter érkezik az alábbi formában: „091117’. Az első két karakter a napot a következő kettő a hónapot, míg az utolsó két karakter az évszámot jelképezi. Ezt a 6 karaktert az előbb említett felosztásban felosztjuk, majd a „,-" -kel, illetve a „20" kifejezéssel kiegészítve újra összefüzzük a következő képpen: „2017-11-09”. Ez a karakterlánc kerül a mentésre és kijelzésre is.

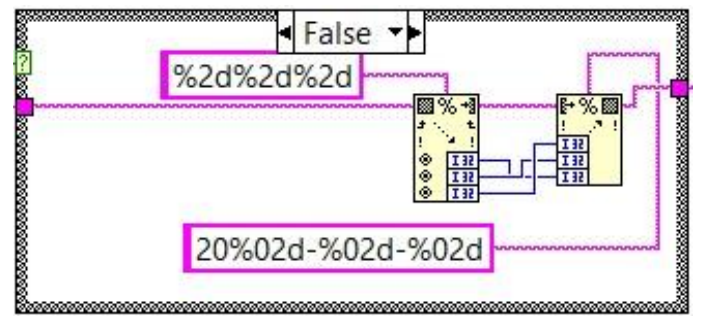

8. ábra Dátum átalakítása
A földrajzi szélesség esetében az adatok pl:4717.11437 formátumban érkeznek, amelyből az első két szám a fokot míg az összes többi karakter a szögperceket jelöli. Ezt a karakterláncot a mentéshez tizedesfokra kellett átalakítani, illetve a megjelenítésnél fok, szögperc, szögmásodperc alakban jelenítettük meg az értékeket.

Az előbbihez az adatról leválasztottuk az első két karaktert, aztán a többi 8 karakterből álló számot tehát a „17.11437” -et elosztottam 60-nal, majd hozzáadtuk az első két karakterből álló számhoz, tehát a , „47” -hez, így végül megkaptuk az értéket tizedes fokban. A fentebb említett példa alapján a mentésre kerülő érték: „47.2852395” lesz. A fölrajzi szélességet $-90^{\circ}-0-90^{\circ}$ között határozták meg. A negatív értékek az egyenlítőtől délre vannak, míg a pozitív értékek az egyenlítőtől északra. Ezt az információt a GPS a földrajzi szélesség után érkező egy karakterből álló (N(Észak) vagy $\mathrm{S}$ (Dél)) üzenettel fejezi ki.

Ez alapján abban az esetben, ha a déli féltekén történne a mérés tehát, a GPS S értéket közvetítene felénk, akkor a példánkban lévő értéket meg kell szorozni -1-gyel, hogy megkapjuk a megfelelő értéket.

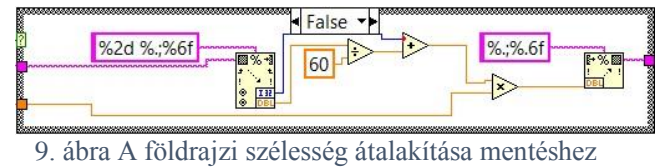

A megjelenítésnél az átalakítás úgy történik, hogy a karakterláncot felosztottuk 2 db 2 jegyü számra a pontra és a maradék számjegyet egy számként kezeltük. Az első kétjegyü szám a fokot jelenti a második a szögpercet a pont utáni karakterláncból álló számot megszoroztuk 60-nal és elosztottuk 100000-el, így megkapva a szögmásodperceket. Ezek alapján a fenti példán bemutatva a kijelzőn megjelenő érték: „47 $47^{\circ} 17$ '6,8622”"'. Ebben az esetben a kijelzésnél ezen felirat után füztük, hogy melyik féltekéről is van szó. Értelem szerüen, ha a GPS N-et küld, akkor a fenti példa úgy néz ki, hogy: „47 17 ' 6,8622” Észak”. S érkezése esetében az Észak felirat Délre módosul.

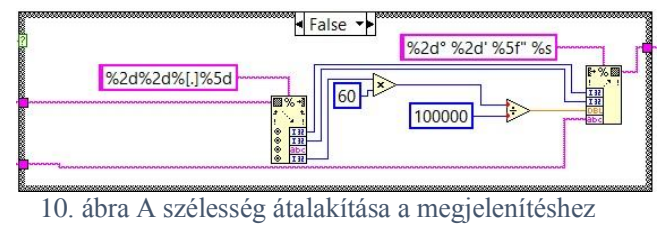

A földrajzi hosszúság átalakítása ugyan ezen az elven alapszik, annyi különbség van csak, hogy mivel a földrajzi szélesség 0-180-ig megy a Greenwich-től keleti, illetve nyugati irányban is ezért az első 3 karakter tartalmazza az értéket fokban. Ebben az esetben, ha Greenwich-től nyugatra vagyunk a GPS által küldött következö üzenet a W karaktert fogja tartalmazni, míg, ha keletre akkor az E karakter fog érkezni.

A mentésnél a számértéket -1-gyel szorozni a W karakter esetén szükséges. Az előbbi minta alapján, ha a beérkező adat: 00833.91522,E, akkor az átalakítás után a kijelzőn megjelenő 
érték: „, $8^{\circ} 33$ ' 54,9132 Kelet”, míg a mentésre kerülő érték: $, 8,565254^{\circ}$ ".

A sebesség esetében azért van szükség átalakításra, mert az adatsorban érkező adat csomómban érkezik. A kijelzőn a megjelenítés $\mathrm{km} / \mathrm{h}$-ban történik, míg a mentéshez $\mathrm{m} / \mathrm{s}-\mathrm{ra}$ van szükség.

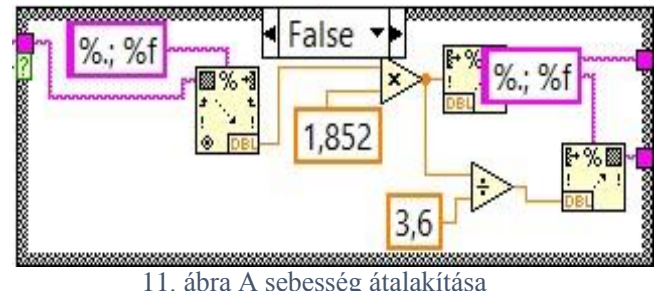

11. ábra A sebesség átalakítása

$$
1 \text { csomó }=1,852 \mathrm{~km} / \mathrm{h}
$$

$$
1 \mathrm{~m} / \mathrm{s}=3,6 \mathrm{~km} / \mathrm{h}
$$

A tengerszint feletti magasságot nem kell átalakítani sem kijelzéshez, sem mentéshez, mivel m-ben kapjuk az értéket.

Ezeken a fentebb említett értékeken kívül kijelzésre kerül még az állapotot tartalmazó adat, amely azt mutatja, hogy érvényes üzenet érkezik e a GPS-től. Ez az adat RMC-s adatsor esetén A (érvényes) vagy $\mathrm{V}$ (érvénytelen) értéket vehet fel, GGA-s adat esetén 0,1,2 és 6-ot., ahol az 1,2 esetén érvényes az érkező adat.

A kijelzőn még megjelenik a müholdak száma, ez az érték nem kerül mentésre a GPX fájlban, ahogy az állapot sem. Ezen kívül még megjelenik a kijelzőn a föld feletti irány is, amelyet fokban kapunk meg az RMC típusú adatban. A mentéshez meg kell adni, hogy hova szeretnénk menteni a fájlt. Abban az esetben, ha ez a fájl már létezik, akkor felül lesz írva, ha pedig nem akkor a program létrehozza azt. Az összes megjelenö üzenetet is elmenti a program egy szöveg fájlba, ennek az elérési útvonalát is meg kell adni, figyelni kell a kiterjesztés megadására.

A GPX fájlba mentésre kerülő adatok kivezetéseinél a csatorna módot (Tunel Mode) sorszámozásra állítottuk (Indexing), így a mérés végén a kivezetéseken 7 adattömb lesz ( idő, szélesség, hosszúság, dátum, magasság, sebesség, jel típusa), amelyek szükségesek a GPX fájlhoz. Az üzenet típusa tömböt, azért kell létrehozni, hogy megtalálhassuk belöle az első elemet, ahol üzenet érkezett, mivel a mérés elején vannak üres üzenetek, így az első pár tömbelem üres. Ahhoz, hogy a mentést elkezdhessük meg kell találni az első RMC-s adatokat.

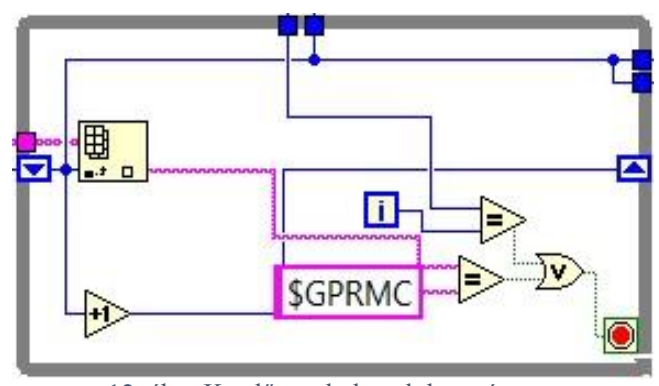

12. ábra Kezdő tömbelemek keresése
Ehhez a jel típusánál keressük a „\$GPRMC tartalmat addig, amíg meg nem találjuk, ha megtaláltuk akkor ennek a while ciklusnak a ciklus számát használjuk fel az RMC-s adatok tömbjeinek kezdőindexeként, hogy velük kezdődjön meg az adatok összefüzése nyomvonalpontokká. Mivel a GGA-s adatok a RMC-s adatok után érkeznek, de ahhoz kiegészítő információt tartalmaznak, így a GGA-s adat tömbök indexe 1gyel nagyobb. A következő lefutás alkalmával mindkét tömbindex kettővel nagyobb lesz. A ciklus feleannyiszor fut le mint, ahányszor lefutott a mérés while ciklusa, illetve ahány adatot tartalmaznak az adott tömbök. Az összefüzés csak akkor történik meg, hogy ha a szélesség, dátum, idő, hosszúság és magasság értékeket is kaptunk a mérés során.

Miután az összes nyomvonalpont összefüződött, azokat ahhoz, hogy GPX fájl legyen belöle össze kell füzni még a GPX fájlnak megfelelő „fejléccel” illetve „lábléccel”. Azért döntöttünk a szövegként történő összefüzés mellett, mivel a LabVIEW csak a saját XML sémáját képes kezelni, illetve bármilyen szöveg szerkesztőben lehet XML fájlt írni, így ez tűnt kézenfekvőnek. Ezzel a lépéssel a programnak vége szakad. Ezek után megnyitható mind az NMEA üzenetek tárolására alkalmazott szövegfájl illetve a GPX fájl. A GPX fájlt fel lehet tölteni annak megjelenítésére alkalmas térkép megtekintő alkalmazásokban pl.: Google Maps, Google Earth. 


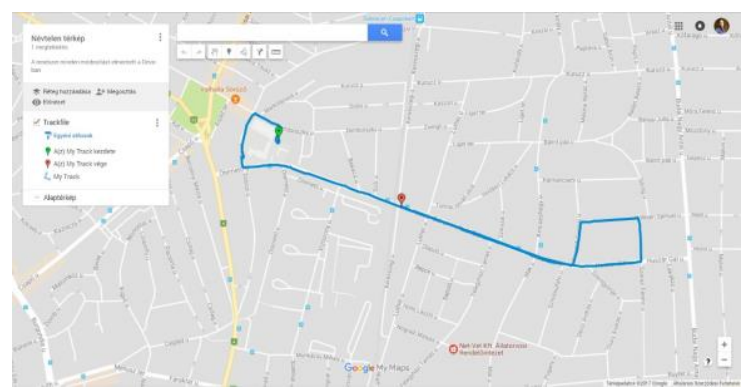

13. ábra A mentett adatok megjelenítés Google Maps-ben

\section{VI. ÖSSZEFOGLALÁS}

Összességben elmondható, hogy kutatómunkában készítettünk egy komplex helymeghatározó programot, amely képes bármilyen típusú GPS modul adatait fogadni soros kommunikáción, értelmezni és feldolgozni az érkező adatokat, illetve szöveges formátumban kimeneti a transzformálatlan adatokat a későbbi feldolgozás érdekében, illetve szabványos GPX formátumú útvonalat készíteni az adatokból. A GPS adatok feldolgozása egy komplex gépjármüdiagnosztikai rendszer részét képezi, amely valós időben képes a gépjármü diagnosztikai csatlakozóján keresztül menetdinamikai adatokat olvasni és vele azonos időben az útvonal adatokat is menteni.

\section{KÖSZÖNETNYILVÁNÍTÁS}

A publikáció/prezentáció/poszter elkészítését az EFOP3.6.1-16-2016-00022 számú projekt támogatta. A projekt az Európai Unió támogatásával, az Európai Szociális Alap társfinanszírozásával valósult meg.

\section{HIVATKOZÁSOK}

[1] Dr. Busics György, "Müholdas helymeghatározás 1., A GNSS-ről általában” Nyugat-magyarországi Egyetem 2010.

[2] Dr. Varga József „GPS alapismeretek kezdőknek” [Online] Elérhető: http://www.agt.bme.hu/staff_h/varga/gps/kezdoknek.html [Hozzáférés dátuma: 2017.10.16.]

[3] [Online]

http://images.slideplayer.com/37/10727197/slides/slide 6.jpg. [Hozzáférés dátuma: 21. 11. 2017.]

[4] I. Dr. Szalai, Mechatronikai rendszerek speciális érzékelői és aktuátorai, Pannon Egyetem, 2014.

[5] NEO-6 series Versatile u-blox 6 GPS modules [Online] Elérhető: https://www.u-blox.com/sites/default/files/products/documents/NEO6_ProductSummary_\%28GPS.G6-HW-09003\%29.pdf [Letöltve: 2017.10.15.]

[6] NEO-6 u-blox 6 GPS Modules Data Sheet [Online] Elérhetö: https://www.u-blox.com/sites/default/files/products/documents/NEO6 DataSheet (GPS.G6-HW-09005).pdf [Letöltve: 2017.10.16]

[7] u-blox 6 Receiver Description Including Protocol Specification [Online] Elérhető:

blox.com/sites/default/files/products/documents/u-

blox6_ReceiverDescrProtSpec_\%28GPS.G6-SW-10018\%29_Public.pdf [Letöltve: 2017.10.16]

[8] NMEA 0183 [Online] Elérhető: http://www.nmea.org/content/nmea standards/nmea 0183 v 410.asp [Hozzáférés dátuma: 2017.10.16]
[9] GPS Exchange Format [Online] Elérhető: http://www.topografix.com/gpx.asp [Hozzáférés dátuma: 2017.10.16] 